Jurnal Keperawatan Silampari

Volume 4, Nomor 2, Juni 2021

e-ISSN: 2581-1975

p-ISSN: 2597-7482

DOI: https://doi.org/10.31539/jks.v4i2.1983

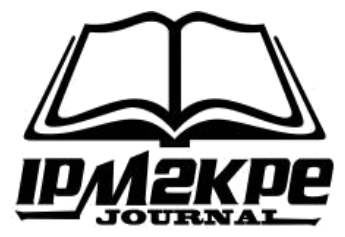

\title{
POSISI PASIEN TERHADAP TEKANAN VENA SENTRAL
}

\author{
Armi $^{1}$, Mila Sartika ${ }^{2}$ \\ Institut Medika Drg Suherman ${ }^{1,2}$ \\ ners.armi@gmail.com ${ }^{1}$
}

\begin{abstract}
ABSTRAK
Penelitian ini bertujuan untuk mengidentifikasi peningkatan tekanan vena sentral pada pasien yang diberikan intervensi posisi lateral atau supinasi dan mengidentifikasi peningkatan tekanan vena sentral pada pasien yang diberikan intervensi posisi semi fowler di ruang intensive care unit. Penelitian ini menggunakan metode quasiexperimental dengan desain case control. Hasil yang diperoleh yaitu $p$ value 0,000 , berarti penelitian terdapat pengaruh yang signifikan pemberian posisi terhadap tekanan vena sentral (CVP). Simpulan, terjadi peningkatan nilai CVP rata-rata sebelum dan sesudah diberikan intervensi posisi supine sebesar $-1.967 \mathrm{cmH} 2 \mathrm{O}$, sebaliknya terjadi penurunan nilai CVP rata-rata sebelum dan sesudah diberikan intervensi posisi semi fowler sebesar 1.867 $\mathrm{cmH} 2 \mathrm{O}$.
\end{abstract}

Kata Kunci: Posisi Supine dan Semi Fowler, Tekanan Vena Sentral

\begin{abstract}
This study aims to identify an increase in central venous pressure in patients given lateral or prone position interventions and to identify the rise in central venous pressure in patients given semi-fowler position intervention in the intensive care unit. This study uses a Quasi-Experimental method with a Case-Control design. The results obtained are the p-value of 0.000 , meaning that the research significantly affects the positioning of the central venous pressure (CVP). In conclusion, there was an increase in the average CVP value before and after the passive position intervention was -1,967 $\mathrm{cmH} 2 \mathrm{O}$; on the other hand, there was a decrease in the average CVP value before and after the semi fowler position intervention was 1,867 $\mathrm{cmH} 2 \mathrm{O}$.
\end{abstract}

Keywords: Supine and Semi Fowler Position, Central Venous Pressure

\section{PENDAHULUAN}

Pasien dengan kondisi kritis memerlukan pemantauan hemodinamik yang sangat ketat dan tidak dapat diberikan di ruang perawatan umum, sehingga diperlukan untuk perawatan di unit intensif untuk mengurangi kesakitan dan kematian. Kesalahan terbanyak yang menyebabkan angka kematian tertinggi di rumah sakit karena resusitasi cairan yang tidak adekuat dan menghabiskan waktu yang lama untuk masa rawat di rumah sakit karena terjadi perubahan besar pada sistem kardiovaskular saat bedrest (Guedes et al., 2018).

Salah satu pemantauan hemodinamik yaitu dengan pemantauan nilai tekanan vena sentral. CVP (Central Venous Pressure) sering digunakan pada pasien yang mengalami gangguan keseimbangan cairan. CVP sebagai parameter pemantauan yang dapat 
menggambarkan volume intravascular, sehingga nilai CVP rendah menandakan pasien dalam keadaan kekurangan cairan dan sebaliknya (Djalil et al., 2020). Resusitasi cairan merupakan masalah pada pasien kritis yang mengalami syok, dimana angka kematian pasien disebabkan syok hipovolemik sekitar 30-90\% (Suresh et al., 2019).

Pasien yang terpasang CVP sangat diperlukan pemantauan yang akurat terhadap pengukuran CVP, karena perubahan nilai CVP sangat mempengaruhi hemodinamik dan status cairan dalam tubuh pasien, sehingga perubahan nilai CVP pada pasien dibutuhkan untuk menentukan nilai CVP yang bermakna (Shojaee et al., 2017). Perawat mempunyai peran penting dalam hal ini, sehingga perawat yang bertugas di ruang intensif harus memiliki pengetahuan dan keterampilan yang baik dalam hal pengukuran dan pemantauan tekanan vena sentral (Lesmana et al., 2019). Pemantauan tekanan vena sentral dapat mempengaruhi nilai CVP dengan melakukan pengukuran CVP merupakan aktivitas yang dilakukan perawat di ruang ICU seperti head up, memposisikan lateral, ROM dan kolaborasi dengan fisioterapi (Tanujiarso \& Lestari, 2020).

Faktor yang dapat membiaskan hasil pengukuran meningkat/menurun dari nilai pengukuran tekanan vena sentral dapat dipengaruhi oleh banyak faktor diantaranya adalah penggunaan obat vasopressor, gravitasi (posisi pasien) dan faktor kesalahan pengukuran (Lesmana et al., 2019). Pengaturan posisi yang adekuat harus dilakukan perawat pada saat pengukuran tekanan vena sentral, hal ini dapat mempengaruhi sistem hemodinamik dalam menjaga sirkulasi sistemik (Muti, 2020). Posisi supine atau semi fowler dapat dilakukan perawat saat melakukan pengukuran CVP. Posisi yang konstan diperlukan pada saat pengukuran untuk validitas pengukuran dan keakuratan interprestasi tekanan vena sentral (Lesmana et al., 2019). Perubahan posisi pasien berdampak pada perubahan dalam hasil pengukuran pada tekanan vena sentral, faktor gravitasi atau posisi pasien dalam keadaan posisi dari $0^{\circ}, 15^{\circ}, 30^{\circ}$ dan posisi $45^{\circ}$ akan mengalami peningkatan pada nilai tekanan vena sentral. Perubahan dalam posisi responden dari setiap posisi akan menyebabkan suatu perubahan besar dalam hasil pengukuran CVP (Lesmana et al., 2019).

Lateral position atau semi fowler secara tidak langsung meningkatkan curah jantung dan hemodinamik sehingga dapat menjadi sebagai salah satu pilihan tindakan keperawatan pada pasien di ruang perawatan intensif. Hasil penelitian pada 31 pasien gagal jantung kongestif didapatkan adanya pengaruh pemberian posisi semi fowler dengan kombinasi lateral kanan terhadap perubahan status hemodinamik (Muti, 2020). Posisi terlentang membuat $11 \%$ dari volume darah menghilang dari kaki, yang seharusnya banyak menuju dada. Bedrest pada 3 hari pertama volume plasma akan berkurang $8 \%$ sampai $10 \%$, sehingga pada minggu keempat akan mengalami kerugian $15 \%$ sampai $20 \%$ (Guedes et al., 2018). Posisi supine dapat dilakukan karena posisi terlentang/supine lebih dapat meningkatkan tekanan vena sentral lebih dari $4 \mathrm{mmHg}$, Sehingga kebutuhan pasien akan cairan dapat terpantau dengan akurat dan tidak menyebabkan resusitasi cairan yang berlebih yang akan berakibat kepada kematian. Analisa ini menjadi salah satu pertimbangan peneliti untuk mengetahui posisi yang efektif pada pasien yang terpasang CVP, karena posisi berdampak terhadap meningkat atau menurunnya nilai pengukuran CVP, sehingga dapat mencegah terjadinya kesalahan dalam pengambilan keputusan klinik terhadap pasien (Lesmana et al., 2019).

Posisi merupakan salah satu faktor yang harus diperhatikan dalam menjaga sirkulasi sistemik yang adekuat karena dapat mempengaruhi sistem hemodinamik. Salah satu faktor yang harus diperhatikan dalam menjaga sirkulasi sistemik yang dapat mempengaruhi sistem hemodinamik dengan tindakan pengaturan posisi (Muti, 2020). 
Pengukuran CVP yang akurat sangat dibutuhkan oleh pasien yang dirawat di ICU, oleh karena itu pengaturan posisi harus diperhatikan oleh perawat sesuai dengan kebutuhan pasien saat dilakukan pengukuran CVP, sehingga hemodinamik pasien dapat terpantau. Peran penting dalam manajemen pasien dengan kondisi kritis dengan pemantauan hemodinamik. Dasar pemantauan hemodinamik memiliki tujuan untuk mendeteksi kelainan fisiologis secara dini dan memantau pengaruh perubahan posisi yang diberikan baik posisi supine atau datar dan semi fowler.

Penelitian sebelumnya terkait posisi semi fowler dengan kombinasi lateral kanan berpengaruh terhadap perubahan hemodinamik pada pasien gagal jantung kongestif di ruang ICCU RSUD Prof. dr. Margono Soekardjo Purwokerto telah dilakukan oleh Refa Teja Muti pada tahun 2020, tetapi untuk efektifitas posisi semi fowler dan supine atau lateral belum dilakukan. Di Rumah Sakit Sentra Medika Cibinong untuk tindakan pengaturan posisi baik semi fowler dan supine belum tercantum dalam SOP tindakan pengukuran CVP dan tindakan tersebut masih menyatu dengan tindakan pemasangan CVP yang dilakukan oleh dokter. Seorang perawat di ruang ICU harus memperhatikan pengaturan posisi pada saat tindakan pengukuran CVP karena hal ini akan berakibat kepada akurasi dalam pemantauan cairan pasien, sehingga masalah cairan pasien dapat teratasi dengan baik. Melihat pentingnya mencantumkan pengaturan posisi pasien baik semi fowler dan supine, sehingga mencegah terjadinya resusitasi cairan berlebih yang akan menyebabkan terjadinya kematian. Berdasarkan hal tersebut maka diperlukan SOP pengukuran CVP yang didalamnya terdapat pengaturan posisi baik semi fowler dan supine sehingga berdampak pada akurasi dan ketepatan dalam hasil pengukuran CVP.

\section{METODE PENELITIAN}

Penelitian ini merupakan penelitian ekperimental semu (quasi-experimental resarch) dengan desain penelitian case control. Studi kasus kontrol dilakukan dengan mengindentifikasi kelompok kasus dan kelompok kontrol. Dalam penelitian ini kelompok kasus (case) yaitu kelompok responden yang menggunakan posisi supine dan terpasang CVP sedangkan kelompok kontrol yaitu kelompok responden dengan posisi semi fowler dan terpasang CVP. Penelitian ini menggunakan uji T test.

\section{HASIL PENELITIAN}

\section{Analisa Univariat}

Tabel. 1

Distribusi Responden Berdasarkan Jenis Kelamin dengan Posisi Pasien terhadap Tekanan Vena Sentral di Ruang ICU

\begin{tabular}{ccc}
\hline Jenis Kelamin & Frekuensi & $\%$ \\
Perempuan & 13 & 43,3 \\
Laki-Laki & 17 & 56,7 \\
Total & 30 & 100 \\
\hline
\end{tabular}

Berdasarkan tabel 1 dapat dilihat bahwa responden yang diberikan posisi supine dan semi fowler yang berjenis kelamin perempuan yaitu sebanyak 13 orang $(43,3 \%)$ dan berjenis kelamin laki-laki sebanyak 17 orang $(56,7 \%)$. 
Tabel. 2

Distribusi Responden Berdasarkan Umur dengan Posisi Pasien terhadap Tekanan Vena Sentral di Ruang ICU

\begin{tabular}{ccccc}
\hline Variabel & Mean & Std. Deviasi & Min-Maks & $95 \%$ CI \\
Umur & 50,03 & 14,02 & $21-77$ & $44,8-55,3$ \\
\hline
\end{tabular}

Berdasarkan tabel 2 dapat dilihat bahwa rata-rata umur responden yang diberikan posisi supine dan semi fowler yaitu 50,03 tahun (95\% CI (44.80 - 55.27) dengan standar deviasi 14.02 tahun. Umur termuda yaitu 21 tahun dan yang tertua 77 tahun.

\section{Analisa Bivariat}

Tabel. 3

Efektifitas Posisi Pasien terhadap

Tekanan Vena Sentral di Ruang ICU

\begin{tabular}{ccccccc}
\hline Posisi Pasien & Nilai $C V P$ & N & Mean & Std. Deviasi & Std. Eror & p Value \\
\hline \multirow{2}{*}{ Supine } & Sebelum & 15 & 6,000 & 2,536 & 0,655 & \multirow{2}{*}{0,000} \\
& Sesudah & 15 & 7,967 & 2,518 & 0,650 & \multirow{2}{*}{ Semi fowler } \\
& Sebelum & 15 & 8,133 & 2,906 & 0,750 & \multirow{2}{*}{0,000} \\
& Sesudah & 15 & 6,267 & 2,896 & 0,748 & \\
\hline
\end{tabular}

Berdasarkan tabel 3 dapat dilihat bahwa nilai CVP rata-rata pada responden sebelum diberikan posisi supine yaitu sebesar 6,000 $\mathrm{cmH} 2 \mathrm{O}$ dan standar deviasi 2,536 cmH2O. Responden sesudah diberikan posisi supine nilai CVP rata-rata yaitu 7,967 $\mathrm{cmH} 2 \mathrm{O}$ dan standar deviasi $2,518 \mathrm{cmH} 2 \mathrm{O}$. Terlihat nilai rata-rata sebelum dan sesudah diberikan posisi supine adalah $-1,967 \mathrm{cmH} 2 \mathrm{O}$ dengan standar deviasi $0,834 \mathrm{cmH} 2 \mathrm{O}$. Nilai $p$ value sebelum dan sesudah diberikan posisi supine yaitu 0,000.

Nilai CVP rata-rata pada responden sebelum diberikan posisi semi fowler yaitu sebesar 8,133 $\mathrm{cmH} 2 \mathrm{O}$ dengan standar deviasi 2,906 $\mathrm{cmH} 2 \mathrm{O}$. Responden sesudah diberikan posisi semi fowler nilai CVP rata-rata yaitu $6,267 \mathrm{cmH} 2 \mathrm{O}$ dengan standar deviasi 2,896 cmH2O. Terlihat nilai rata-rata sebelum dan sesudah diberikan posisi semi fowler adalah 1,867 $\mathrm{cmH} 2 \mathrm{O}$ dengan standar deviasi $1,408 \mathrm{cmH} 2 \mathrm{O}$. Nilai $p$ value sebelum dan sesudah diberikan posisi semi fowler yaitu 0,000 .

\section{PEMBAHASAN}

\section{Posisi Supine atau Datar dengan Tekanan Vena Central}

Hasil penelitian yang dilakukan diketahui bahwa nilai CVP rata-rata pada responden sebelum diberikan posisi supine yaitu sebesar $6,000 \mathrm{cmH} 2 \mathrm{O}$ dan nilai ratarata sesudah diberikan posisi supine adalah 7,967 $\mathrm{cmH} 2 \mathrm{O}$. Terjadi peningkatan nilai CVP rata-rata sebelum dan sesudah diberikan intervensi posisi supine sebesar -1.967 $\mathrm{cmH} 2 \mathrm{O}$ dengan standar deviasi $0,834 \mathrm{cmH} 2 \mathrm{O}$. Nilai $p$ sebelum dan sesudah diberikan posisi supine yaitu 0,000 .

Pengaturan posisi yang adekuat dapat mempengaruhi sistem hemodinamik dalam menjaga sirkulasi sistemik (Muti, 2020). Pengaturan posisi dapat mempengaruhi keakuratan dalam hasil pengukuran CVP. Posisi terlentang atau supine yang konstan dapat dilakukan dilakukan, agar kebutuhan resusitasi cairan pada pasien dapat tertangani dengan baik. Validitas pengukuran dan keakuratan interprestasi tekanan vena sentral diperlukan posisi yang konstan, jika mungkin posisi terlentang (Lesmana et al., 
2019). Posisi terlentang membuat $11 \%$ dari volume darah menghilang dari kaki, yang seharusnya banyak menuju dada. Bedrest pada 3 hari pertama volume plasma akan berkurang $8 \%$ sampai $10 \%$, sehingga pada minggu keempat akan mengalami kerugian 15\% sampai 20\% (Lesmana, 2018).

Posisi supine dapat dilakukan karena posisi terlentang/supine lebih dapat meningkatkan tekanan vena sentral lebih dari $4 \mathrm{mmHg}$, sehingga kebutuhan pasien akan cairan dapat terpantau dengan akurat dan tidak menyebabkan resusitasi cairan yang berlebih yang akan berakibat kepada kematian (Lesmana, 2018). Resusitasi cairan pada pasien harus terpantau dengan baik, sehingga hal tersebut dapat mengatasi timbulnya syok yang sering dilalami pada pasien yang dalam kondisi kritis. Resusitasi cairan merupakan masalah pada pasien kritis yang mengalami syok, dimana angka kematian pasien disebabkan syok hipovolemik sekitar 30-90\% (Suresh et al., 2019). Oleh karena itu diperlukan posisi yang akurat dalam resusitasi cairan pada pasien ICU. Posisi supine merupakan referensi yang tepat untuk menjamin akurat pengukuran tekanan vena sentral (Song et al., 2017).

\section{Posisi Semi Fowler dengan Tekanan Vena Central}

Hasil penelitian yang dilakukan diketahui bahwa nilai CVP rata-rata pada responden sebelum diberikan posisi semi fowler yaitu sebesar $8,133 \mathrm{cmH} 2 \mathrm{O}$ dan nilai rata-rata sesudah diberikan posisi semi fowler nilai CVP rata-rata yaitu 6,267 $\mathrm{cmH} 2 \mathrm{O}$. Terjadi penurunan nilai CVP rata-rata sebelum dan sesudah diberikan intervensi posisi semi fowler sebesar $1.867 \mathrm{cmH} 2 \mathrm{O}$ dengan standar deviasi 1,408 $\mathrm{cmH} 2 \mathrm{O}$. Nilai $p$ sebelum dan sesudah diberikan posisi semi fowler yaitu 0,000.

Perubahan posisi pasien berdampak pada perubahan dalam hasil pengukuran pada tekanan vena sentral, faktor gravitasi atau posisi pasien dalam keadaan posisi dari $0^{\circ}$, $15^{\circ}, 30^{\circ}$ dan posisi $45^{\circ}$, mengalami peningkatan pada nilai tekanan vena sentral. Perubahan dalam posisi responden dari setiap posisi akan menyebabkan suatu perubahan besar dalam hasil pengukuran CVP (Lesmana, 2018). Posisi merupakan salah satu tindakan keperawatan yang dilakukan untuk mempengaruhi perubahan kondisi hemodinamik pasien. Pemberian posisi pasien dengan posisi miring (lateral position) menjadi standar perawatan dalam pengukuran tekanan vena sentral. Pemberian posisi fowler $60^{\circ}$ dapat memberikan pengaruh terhadap hemodinamik seperti penurunan perfusi serebral, penurunan MAP dan Central Venous Pressure (CVP) akibat menurunnya beban awal pada jantung (preload) dan paru, kongesti paru berkurang dan penekanan hepar ke diafragma menjadi minimal yang akan berdampak pada penurunan curah jantung yang akan berdampak pada denyut jantung dan tekanan darah hingga $20 \%$ (Muti, 2020).

Lateral position atau semi fowler secara tidak langsung meningkatkan curah jantung dan hemodinamik sehingga dapat menjadi sebagai salah satu pilihan tindakan keperawatan pada pasien di ruang perawatan intensif. Hasil penelitian pada 31 pasien gagal jantung kongestif didapatkan adanya pengaruh pemberian posisi semi fowler dengan kombinasi lateral kanan terhadap perubahan status hemodinamik (Muti, 2020).

Posisi semi fowler dapat dilakukan jika pasien mengalami peningkatan nilai CVP sehingga terjadi penurunan nilai CVP. Secara tidak langsung keadaan curah jantung meningkat dan hemodinamik menuju kearah perbaikan. Perubahan posisi dari $30^{\circ}$ dengan posisi kepala netral, kemudian miring ke arah kanan dan miring ke arah kiri kemudian dilakukan pengukuran tekanan vena sentral dengan nilai perbedaan sampai 1 cmH2O (Setiyawan et al., 2019). Posisi lateral merupakan posisi yang berfungsi sebagai 
pemantauan vena dan arteri pulmonalis oklusi, sehingga perubahan dalam darah arteria yang meningkat harus menjadi pertimbangan ketika terjadi perubahan pada tekanan vena sentral (Song et al., 2017). Posisi lateral kanan dapat menyebabkan beban kerja jantung yang lebih kecil pada fungsi pernapasan sehingga posisi lateral kanan sangat berpengaruh terhadap peningkatan saturasi oksigen $(\mathrm{SaO} 2)$ dan respirasi.

\section{SIMPULAN}

Berdasarkan hasil penelitian yang telah dilakukan, peneliti dapat menyimpulkan ada pengaruh yang signifikan pemberian posisi supine dan semi fowler terhadap tekanan vena sentral.

\section{SARAN}

Hasil penelitian ini dapat dijadikan pedoman dan rujukan dalam pembuatan standar operasional prosedur pengukuran CVP pada pasien dengan posisi supine atau semi fowler. Pengukuran CVP dengan baik dan benar akan memperoleh hasil penilaian cairan yang akurat sehingga pemberian asuhan keperawatan yang optimal ke pasien.

\section{DAFTAR PUSTAKA}

Djalil, N. K., Sjattar, E. R., \& Syahrul, S. (2020). Pengaruh PEEP terhadap CVP pada Pasien yang terpasang Ventillator Mekanik: Literatur Review. Jurnal Keperawatan Muhammadiyah, 5(2), 150-157. https://doi.org/DOI: http://dx.doi.org/10.30651/jkm.v5i2.4816

Guedes, L. P. C. M., Oliveira, M. L. C., \& Carvalho, G. A. (2018). Deleterious Effects of Prolonged Bed Rest on the Body Systems of the Elderly - A Review. Revista Brasileira de Geriatria E Gerontologia, 21(4), 499-506. https://doi.org/10.1590/1981-22562018021.170167

Lesmana, H. (2018). Akurasi Pengukuran Tekanan Vena Sentral. Journal of Borneo Holistic Health, 1(1), 1-13. http://jurnal.borneo.ac.id/index.php/borticalth/article/view/388

Lesmana, H., Ose, M. I., Zulfia, R., \& Tobing, K. I. S. (2019). The Effect of Changes in Postural Position Angle Degree on Central Venous Pressure Measurement. Indonesian Journal of Medicine, 4(3), 192-200. https://doi.org/10.26911/theijmed.2019.04.03.01

Muti, R. T. (2020). Pengaruh Posisi Semi Fowler dengan Kombinasi Lateral Kanan terhadap Perubahan Haemodinamik pada Pasien Gagal Jantung di Ruang Iccu Rumah Sakit Umum Daerah Margono Soekarjo Purwokerto. VIiva Medika, 13(2), 50-63. https://ejournal.uhb.ac.id/index.php/VM/article/view/519

Setiyawan, S., Ibrahim, K., \& Mulyati, T. (2019). Comparison of Central Venous Pressure (Cvp) Score Among Patients on Mechanical Ventilator With Head of Bed (Hob) Elevation 30O; Neutral, Right, and Left Side Positions. Jurnal Keperawatan Padjadjaran, 7(1). https://doi.org/10.24198/jkp.v7i1.741

Shojaee, M., Sabzghabaei, A., Alimohammadi, H., Derakhshanfar, H., Amini, A., \& Esmailzadeh, B. (2017). Effect of Positive End-Expiratory Pressure on Central Venous Pressure in Patients under Mechanical Ventilation. Emergency (Tehran, Iran), 5(1), e1. https://doi.org/10.22037/emergency.v5i1.11245 
Song, I. K., Park, H. S., Lee, J. H., Kim, E. H., Kim, H. S., Bahk, J. H., \& Kim, J. T. (2017). nary Arteri Occlusion Pressure Monitoring in Supine, Prone, and Sitting Position. Journal of Clinical Monitoring and Computing, 31(2), 381-386. https://doi.org/https://doi.org/10.1007/s10877-016-9864-2

Suresh, M. R., Chung, K. K., Schiller, A. M., Holley, A. B., Howard, J. T., \& Convertino, V. A. (2019). Unmasking the Hypovolemic Shock Continuum: The Compensatory Reserve. In Journal of Intensive Care Medicine (Vol. 34, Issue 9, pp. 696-706). https://doi.org/10.1177/0885066618790537

Tanujiarso, B. A., \& Lestari, D. F. A. (2020). Mobilisasi dini pada pasien kritis di Intensive Care Unit (ICU). Jurnal Keperawatan Widya Gantari Indonesia, 4(1), 59-66. https://ejournal.upnvj.ac.id/index.php/Gantari/article/view/1589 